Wojciech Odrowąż-Sypniewski

\title{
Tryb zwoływania posiedzeń komisji sejmowych ${ }^{1}$
}

The procedure for convening sittings of Sejm committees: The power of the presidium of the committee to determine the agenda of a committee sitting is limited only in two cases - a minority request to convene a sitting and an initiative of the Presidium of the Sejm. The chairperson of the committee establishes the agenda of the committee meeting only in the case in which he executes the minority's request. No provision of the Standing Orders of the Sejm I allows the chairman of the committee to set the agenda for a committee meeting without the involvement the presidium of the committee. Producing minutes documenting a sitting of the presidium is not required, nor there are any procedural requirements regarding the rules for convening these sittings.

Keywords: parliamentary committee | Standing Orders of the Sejm

Słowa kluczowe: komisja sejmowa | regulamin Sejmu

Ekspert ds. legislacji BAS; wojciech.sypniewski@sejm.gov.pl.

\section{Przedmiot opinii}

Przedmiotem opinii jest odpowiedź na pytania dotyczące trybu zwoływania posiedzeń komisji sejmowych. Sygnalizowane wątpliwości zostały wyrażone w następujących pytaniach:

- czy regulamin Sejmu (lub inne przepisy) wprowadzają wymóg sporządzania protokołu/sprawozdania z posiedzenia prezydium komisji?

- czy błędem jest zwołanie posiedzenia komisji przez przewodniczącego bez uprzedniego ustalenia $\mathrm{z}$ prezydium komisji?

1 Opinia prawna w sprawie trybu zwoływania posiedzeń komisji sejmowych sporządzona 25 lipca 2017 r. na zlecenie Klubu Parlamentarnego Prawo i Sprawiedliwość; BAS-WAKiU 1491/17. 


\section{Organizacja prac komisji sejmowej}

Organem kierowniczym komisji sejmowej - w sensie organizacyjnym - jest prezydium komisji. Stosownie do art. 150 ust. 1 regulaminu Sejmu: [p] rezydium komisji kolegialnie kieruje pracami komisji, a w szczególności: 1) opracowuje projekty planów pracy komisji, 2) ustala terminy i porządek dzienny posiedzeń, 3) czuwa nad przygotowaniem posiedzeń, 4) zapewnia członkom komisji otrzymywanie $w$ odpowiednim czasie należycie przygotowanych materiałów, 5) wyznacza sprawozdawców (referentów) na posiedzenia komisji.

W przyjętym w regulaminie Sejmu modelu normatywnym kompetencja prezydium komisji nie ogranicza się tylko do określenia terminów posiedzeń i ich porządków dziennych. Uprawnienie to koresponduje bowiem z innymi regulaminowymi zadaniami tego organu. Obowiązek określania planu pracy komisji stanowić ma gwarancję takiego trybu działania, w którym prace komisji prowadzone są w sposób uporządkowany i przemyślany. „Plan pracy” służy wyznaczeniu kolejnych etapów działań komisji oraz sposobu dochodzenia do zamierzonego rezultatu. Projekt przygotowany przez prezydium komisji winien uwzględniać sugestie tych członków, którzy nie zasiadają w prezydium (stosownie do art. 150 ust. 2 regulaminu Sejmu prezydium komisji, opracowując projekty planów pracy komisji oraz ustalając porządek dzienny posiedzenia, zobowiązane jest brać pod uwagę „wnioski klubów i kół poselskich oraz poszczególnych posłów”). Obowiązek przygotowania planu pracy komisji wiąże się z kompetencją do „wyznaczenia sprawozdawców (referentów) na posiedzenia komisji”. Prawo wyznaczenia referentów na poszczególne posiedzenia komisji widzieć należy w powiązaniu z planem pracy, zakładającym realizację celów cząstkowych. Innymi słowy, chodzi o to, że poszczególnym członkom komisji prezydium może powierzyć merytoryczne przygotowanie konkretnych zagadnień, które rozpatrywane są przez komisję. Działania prezydium w tym zakresie - z natury rzeczy - nie mają charakteru władczego. „Wyznaczenie referenta” dla swojej skuteczności musi zyskać zarówno akceptację osoby „wyznaczonej”, jak i aprobatę większości członków komisji.

Prezydium komisji odpowiada także za organizacyjno-techniczne przygotowanie pracy komisji. Domenę działań prezydium wyznacza nakaz czuwania nad przygotowaniem posiedzeń i obowiązek zapewnienia członkom komisji otrzymywania $w$ odpowiednim czasie należycie przygotowanych materiałów. Obok omówionych wyżej uprawnień wiążących się ściśle ze sprawami organizacyjnymi prezydium komisji przysługują również kompetencje zewnętrzne. Zgodnie $\mathrm{z}$ art. 150 ust. 4 regulaminu Sejmu prezydium komisji może zwrócić się do właściwych organów, instytucji i organizacji o przedstawienie stanowiska w sprawie wniosku lub uwagi wypowiedzianej przez posła w toku posiedzenia komisji. Ponadto na żądanie prezydium komisji ministrowie oraz kierownicy naczelnych organów administracji państwowej, a także kierownicy innych urzędów i instytucji 
państwowych są obowiązani przedstawiać sprawozdania i udzielać informacji oraz uczestniczyć w posiedzeniach komisji, na których rozpatrywane są sprawy dotyczące ich zakresu działania (art. 153 ust. 1 regulaminu Sejmu). Prezydium komisji zobowiązane jest również informować Prezydium Sejmu o przebiegu prac komisji (art. 150 ust. 3).

Istota wątpliwości wnioskodawcy wiąże się z uprawnieniem do ustalania przez prezydium komisji terminów i porządków dziennych posiedzeń komisji (art. 150 ust. 1 pkt 2 regulaminu Sejmu). Realizując tę kompetencję, prezydium powinno brać pod uwagę wnioski klubów i kół poselskich oraz poszczególnych posłów (art. 150 ust. 2). Od powyższych zasad regulamin przewiduje dwa wyjątki. Po pierwsze, Prezydium Sejmu może zwołać posiedzenie komisji w celu rozpatrzenia określonej sprawy, wyznaczając jego termin. Posiedzeniu zwołanemu w tym trybie może przewodniczyć Marszałek Sejmu (art. 152 ust. 3 regulaminu Sejmu). Po drugie, na pisemny wniosek co najmniej 1/3 ogólnej liczby członków komisji przewodniczący komisji obowiązany jest zwołać posiedzenie komisji w celu rozpatrzenia określonej sprawy. Zwołując posiedzenie w tym trybie, przewodniczący komisji wyznacza termin posiedzenia tak, aby odbyło się ono w terminie 30 dni od dnia złożenia wniosku (art. 152 ust. 2).

Od pojęcia „kierowania pracami” komisji odróżnić należy „kierowanie obradami komisji”. Uprawnienie to - w myśl art. 151 ust. 3 regulaminu Sejmu - przysługuje przewodniczącemu komisji, a w razie jego nieobecności - jego zastępcy. Przyjęty w regulaminie Sejmu model dystrybucji kompetencji kierowniczych w komisjach sejmowych wskazuje, że przewodniczącemu powierzone zostały wyłącznie obowiązki związane z prowadzeniem obrad komisji oraz zwoływaniem posiedzeń komisji. Przewodniczący komisji, obok prezydium i komisji in corpore, uczestniczy w ustalaniu terminów posiedzeń komisji (art. 152 ust. 1 i 2). Do obowiązków przewodniczącego należy również formalna czynność zwołania posiedzenia, z czym wiąże się obowiązek zawiadomienia jego uczestników o terminie i porządku dziennym posiedzenia. Zgodnie z art. 152 ust. 5 regulaminu Sejmu przewodniczący komisji zobowiązany jest zawiadomić w imieniu komisji o terminie i porządku dziennym posiedzenia wszystkich członków komisji, Prezydium Sejmu oraz właściwe (zainteresowane) organy państwowe. Zawiadomienie powinno nastąpić co najmniej na trzy dni przed posiedzeniem komisji na zasadach określonych przez Prezydium Sejmu i w trybie określonym przez ten organ. Ponadto przewodniczący komisji ma obowiązek zawiadomić Marszałka Sejmu o terminie i porządku dziennym planowanego posiedzenia, który może nie wyrazić zgody na jego odbycie (art. 152 ust. 4 regulaminu Sejmu).

Relacja między art. 150 ust. 1 pkt 2 oraz art. 152 ust. 1-3 wskazuje, że monopol prezydium komisji w zakresie ustalenia porządku dziennego posiedzenia komisji doznaje ograniczeń jedynie w dwóch omówionych wyżej sytuacjach (wniosek mniejszości o zwołanie posiedzenia oraz inicjatywa Prezydium Sejmu). Przewodniczący komisji samodzielnie ustala porządek dzienny posiedzenia ko- 
misji wyłącznie w przypadku, w którym realizuje wniosek mniejszości. Również w takim wypadku swoboda działań przewodniczącego związana jest obowiązkiem realizacji celu ujętego we wniosku mniejszości „rozpatrzenie określonej sprawy"). Żaden inny przepis regulaminu Sejmu nie pozwala przewodniczącemu komisji na określanie porządku dziennego posiedzenia komisji z pominięciem prezydium komisji.

Odpowiedź na drugie pytanie sformułowane we wstępie niniejszej opinii wiąże się z kwestią dokumentowania ustaleń podjętych przez prezydium komisji. Regulamin Sejmu nie wymaga w tym zakresie sporządzania protokołu z posiedzenia prezydium, jak również nie formułuje żadnych wymogów proceduralnych dotyczących zasad zwoływania tych posiedzeń poza ogólną zasadą odnoszącą się do trybu, w którym prezydium komisji dokonuje swoich rozstrzygnięć. W myśl art. 150 ust. 5 regulaminu Sejmu prezydium podejmuje uchwały większością głosów, a w razie równej liczby głosów decyduje głos przewodniczącego. Nie ma zatem formalnych przeszkód, aby rozstrzygnięcia prezydium komisji dokonywane były w trybie odformalizowanym przy założeniu zachowania wymogów wynikających $\mathrm{z}$ art. 150 ust. 5 .

Rekonstrukcja normatywnego modelu organizacji prac komisji sejmowych, który wyłania się z przepisów regulaminu Sejmu, nie byłaby pełna bez uwag odnoszących się do praktyki parlamentarnej. Trudno bowiem nie dostrzec, że na przestrzeni kilku ostatnich kadencji Sejmu zasada kolegialnego kierownictwa prac komisji podlegała istotnej deprecjacji. Rosnąca dynamika działań komisji sejmowych i konieczność sprawnego reagowania na wydarzenia parlamentarne powoduje, że przewodniczący komisji w praktyce odgrywają daleko większą rolę niż ta, która zarysowana została w przepisach regulaminu Sejmu. Przewodniczący komisji uczestniczą w realizacji obowiązku organizacji prac komisji w zakresie, który nie znajduje uzasadnienia normatywnego. W wielu wypadkach podejmowane przez nich ad hoc rozstrzygnięcia dopiero ex post zyskują aprobatę większości członków prezydium komisji. Rozbieżności między praktyką i modelem opisanym w regulaminie Sejmu nie stanowią jednak przesłanki, która uzasadniać może odstąpienie od jednoznacznych założeń normatywnych. Natomiast świadomość tej rozbieżności dać powinna impuls dla rozważenia celowości dokonania zmian w regulaminie Sejmu.

\section{Podsumowanie}

- Relacja między art. 150 ust. 1 pkt 2 oraz art. 152 ust. 1-3 regulaminu Sejmu wskazuje, że monopol prezydium komisji w zakresie ustalenia porządku dziennego posiedzenia komisji doznaje ograniczeń jedynie $\mathrm{w}$ dwóch wypadkach (wniosek mniejszości o zwołanie posiedzenia - art. 152 ust. 2 oraz inicjatywa prezydium Sejmu - art. 152 ust. 3). Przewodniczący komisji 
samodzielnie ustala porządek dzienny posiedzenia komisji wyłącznie wtedy, kiedy realizuje wniosek mniejszości. Również w takiej sytuacji jego swoboda związana jest obowiązkiem realizacji celu ujętego we wniosku mniejszości („rozpatrzenie określonej sprawy”). Żaden inny przepis regulaminu Sejmu nie pozwala przewodniczącemu komisji na określanie porządku dziennego posiedzenia komisji z pominięciem prezydium komisji.

- Regulamin Sejmu nie wymaga sporządzania protokołu z posiedzenia prezydium, jak również nie formułuje żadnych wymogów proceduralnych dotyczących zasad zwoływania tych posiedzeń, poza ogólną zasadą odnoszącą się do trybu, w którym prezydium komisji dokonuje swoich rozstrzygnięć (art. 150 ust. 5). Nie ma zatem formalnych przeszkód, aby rozstrzygnięcia prezydium komisji dokonywane były w trybie odformalizowanym przy założeniu zachowania wymogów wynikających z art. 150 ust. 5 regulaminu Sejmu. 